\title{
Práticas de leitura entre alunos do terceiro ano do ensino médio: um estudo de caso
}

\author{
Mayara Pereira Dau \\ Universidade Federal da Grande Dourados
}

\author{
Alexandra Santos Pinheiro \\ Universidade Federal da Grande Dourados
}

\begin{abstract}
Resumo
O presente artigo apresenta os resultados de uma pesquisa realizada nos terceiros anos do Ensino Médio das Escolas Estaduais Presidente Vargas e Menodora Fialho de Figueiredo, do município de Dourados - MS. Para a realização da mesma, foi feita uma entrevista filmada dos alunos com base em questões relacionadas à leitura e à Literatura. Com isso, pretendia-se verificar as práticas de leitura desses alunos, levantar quais são as leituras "cobradas" pelos professores nessa disciplina e, principalmente, saber se estão saindo da escola como leitores ou não leitores. Ao final, concluiu-se que os alunos têm, sim, interesse em ler, mas leituras diferentes daquelas que a escola exige. Assim, este artigo trata da formação de leitores do ponto de vista das "falas" dos alunos.
\end{abstract}

Palavras-chave: formação de leitor; práticas de leitura

\begin{abstract}
:
This article presents the results of a survey conducted in the third year of two State High Schools: Presidente Vargas and Menodora Fialho de Figueiredo in Dourados, MS. The students participated in a filmed interview on issues related to reading and literature. The objective was to verify the reading practices of the students, so that we can find out what the "required" reading is that the teachers select for this subject, and especially whether the students are finishing school as readers or non-readers. We concluded that students do have an interest in reading, but different readings from those which the school requires. Thus, this article deals with the development of readers in terms of student "talk".
\end{abstract}

Keywords: reader development; reading practices

\section{A PREPARAÇÃo}

A formação de leitores é assunto amplamente discutido nos dias de hoje. De acordo com a pesquisa Retratos da Leitura no Brasil, do Instituto Pró-livro, de 2008, o brasileiro lê em média 4,7 livros por ano. Outro dado vem do instituto World Report 
Reports Worldwide, no qual o Brasil se encontra em $27^{\circ}$ lugar em leitura num ranking de 30 países (http://www.universia.com.br/materia.jsd?id=16012 > Acesso em 10 de julho de 2009). Na tentativa de justificar esses dados, fala-se sobre a falta de interesse dos alunos e se discute estratégias, metodologias para atraí-los para a leitura. O professor deixa de ser educador para se tornar “propagandista” da leitura, fazendo “marketing” dos livros para conquistar seus alunos (Lajolo, 1999).

Vários são os culpados apontados: a escola, que é ruim, o professor, que ganha mal, o aluno, que não se interessa, a família, que não incentiva. Em meio a tantas questões e preocupações, procuramos investigar, na cidade de Dourados, MS, como está essa situação: a escola está contribuindo para formação de leitores ou está fazendo o processo contrário?

O foco principal do presente trabalho, portanto, é saber se os alunos estão saindo das escolas como leitores, de modo especial leitores literários, independentes, e se continuarão a ler no decorrer de suas vidas, não por obrigação, mas sim por prazer e em busca de algum sentido. Afinal, as práticas de leitura devem ocorrer efetivamente na escola, mas jamais terminar quando o aluno a deixa. Devem continuar na vida do ser humano e se tornar uma prática social.

Para atingir o objetivo, selecionamos duas das principais escolas estaduais de Dourados: Presidente Vargas e Menodora Fialho de Figueiredo. As duas escolas estão localizadas no centro da cidade e foram escolhidas por serem antigas no município e por serem consideradas instituições de ensino de relevância. Além disso, trata-se de estabelecimentos escolares que oferecem todos os níveis de escolaridade.

A escola estadual Presidente Vargas foi implantada no ano de 1958 e era chamada de "Ginásio Estadual Presidente Vargas". Constitui-se como a primeira, dentre as públicas, a oferecer o ginásio na cidade. Hoje, conta com aproximadamente 2.560 alunos, distribuídos nos três períodos. A escola Menodora Fialho de Figueiredo, por sua vez, tem aproximadamente 1.600 alunos e foi implantada em 12 de junho de 1974 . Possui 20 salas de aula e funciona nos períodos matutino, vespertino e noturno, com os cursos da Educação básica e da Educação de Jovens e Adultos, e é Polo da Educação Especial - Deficiência Auditiva.

O resultado apresentado aqui é fruto da análise de entrevistas realizadas com alunos do $3^{\circ}$ ano do Ensino Médio. Inicialmente, fomos às escolas e solicitamos a colaboração dos alunos para a execução da pesquisa. Entregamos um Pedido de Autorização para que levassem a seus responsáveis, autorizando-os a fornecer sua 
imagem para a entrevista, pois a mesma foi filmada. Após a entrega do Pedido de Autorização com a assinatura dos pais/responsáveis, organizamos grupos de alunos para realizar as entrevistas coletivamente. As perguntas foram feitas com base no seguinte questionário:

a) Em sua casa, há livros? Seus pais costumam ler? O que mais é lido em sua família?

b) Você gosta de ler? (Caso a resposta seja positiva, quem o incentivou?);

c) Qual o último livro que você leu ou está lendo?

d) Qual o último livro que sua professora indicou para você? Por qual motivo ela lhe indicou essa leitura?

e) Que tipo de histórias você mais gosta de ler (poesias, romances, dramas, policial)? Por quê?

f) Liste seus livros favoritos.

g) O que é ler, para você?

h) Você considera que as aulas de Literatura são importantes?

i) Como costumam ser as aulas de Literatura?

j) Você teve algum professor de Literatura que marcou? Por quê?

Além das perguntas acima, surgiram, no decorrer da entrevista, outras questões de relevância que também foram levadas em consideração. A opção pela filmagem deuse por ser uma forma mais dinâmica de realizar a pesquisa e assim registrar todos os lapsos no momento, os quais não seriam possíveis se o registro das falas fosse escrito. Além disso, a filmagem nos permite ler, além do discurso oral, os gestos e as expressões faciais. Realizamos as entrevistas por amostragem, ou seja, entrevistamos uma parcela da quantidade total dos alunos do terceiro ano do Ensino Médio. Não houve um critério definido para a escolha dos entrevistados, apenas deveriam estar cursando o último ano escolar e dispostos a participar espontaneamente, ou seja, nenhum aluno foi obrigado. A decisão por não entrevistar todos os alunos deveu-se à preocupação em não atrapalhar o andamento das atividades normais da escola, já que os alunos, para fornecer a entrevista, deviam se retirar da sala. Por fim, analisamos as falas, que foram utilizadas como corpus neste artigo.

A opção por fazer essa pesquisa com os alunos do $3^{\circ}$ ano do Ensino Médio justificou-se por ser o último ano escolar e o aluno já ter passado por todas as experiências de leitura que a escola ofereceu, além de ser o último ano de contato com a 
disciplina de Literatura. Acreditamos que esta pesquisa tem grande importância pela oportunidade de prestar atenção à opinião dos alunos, dar “voz” aos “protagonistas” da escola. Muitas vezes, há a preocupação com o que os teóricos e professores têm a dizer e se esquece de “dar ouvidos” à parte mais interessada e atingida: os alunos.

O conceito de leitor adotado para esta pesquisa foi definido por Azevedo em seu artigo "Formação de Leitores e Razões para a Literatura", quando ressaltou que "leitores podem ser descritos como pessoas aptas a utilizar textos em benefício próprio (...), seja como instrumento para ampliar sua visão de mundo, (...) seja por puro e simples entretenimento” (2004:38). Ao concluir esse levantamento, verificamos quais são as leituras "cobradas” pelos professores nessa disciplina e com qual objetivo foram adotadas.

Assim, o leitor deste artigo acompanha os resultados dos questionamentos que moveram esta pesquisa: os alunos estão lendo por prazer ou somente para cumprir a tarefa escolar? Estão chegando ao último ano escolar como leitores ou não leitores? Essa formação está ocorrendo na escola ou fora dela?

\section{COM A PALAVRA, OS PROTAGONISTAS}

A questão da formação de alunos leitores é um tema que cada vez mais preocupa professores. Mas, afinal, a escola contribui ou não para a formação de leitores? "Leitor” será abordado neste trabalho como sendo um indivíduo que consegue usufruir das diversas leituras que faz, ou seja, uma pessoa que é capaz de ler um texto e tirar dele somente o que é novo, o que lhe acrescenta algo e, ao mesmo tempo, é capaz de descartar o que não lhe serve (Azevedo, 2004).

Quando se fala em formação de leitores, logo nos remetemos à imagem da escola e dos professores como sendo os únicos responsáveis por tão difícil missão. Realmente, a escola tem grande responsabilidade nessa formação ou não-formação de alunos leitores, mas não podemos esquecer também a função dos governantes, que têm papel fundamental na promoção de políticas públicas para a melhoria da educação, apesar de se acreditar que a leitura do texto escrito deveria se iniciar em casa, junto à família. Entretanto, nossa pesquisa, realizada nas duas maiores escolas de Dourados, demonstra que a maioria dos pais dos alunos não tem o hábito de ler. Quando ocorre a leitura, o mais comum é a leitura de periódicos e jornais. Interessante destacar que os 
poucos pais que foram mencionados pelos alunos como leitores são aqueles que cursam ou cursaram o ensino superior.

A outra parcela leitora foi incentivada por amigos ou iniciou na leitura por vontade própria. Zilberman (1984), em Leitura em Crise na Escola: As Alternativas do Professor (1984), reflete sobre essa responsabilidade dada à escola. Essa tarefa é tão fortemente ligada a ela porque é nessa instituição que os alunos aprendem a ler e escrever, ou seja, são alfabetizados, e essa aquisição da habilidade de ler, de acordo com a autora, é o ponto de partida para o aluno assimilar os valores da sociedade em que vive. Portanto, sendo a escola que conduz o aluno ao ato de ler, espera-se da mesma instituição a formação desse aluno como leitor, tanto que, como afirma Silva: “às vezes, chega-se ao absurdo de conceber o aluno alfabetizado como sinônimo de aluno-leitor" (1998, p.10). Essa expectativa nem sempre se concretiza, pois a aquisição da leitura não garante que essa criança se transforme num leitor, "já que este se define, em princípio, pela assiduidade a uma instituição determinada - a literatura” (Zilberman, 1984:17). Não basta somente ensinar a ler e escrever, mas deve-se também ensinar o indivíduo a fazer o uso da leitura e da escrita em suas práticas cotidianas, para que este se sinta inserido na sociedade em que vive (Soares, 1999).

A resposta dos entrevistados também aponta para a importância da escola no incentivo à leitura. Em resposta à questão sobre a importância das aulas de Literatura, alguns alunos se manifestaram:

“É interessante porque foi através da Literatura que a gente começou a ler mais. Eu, pelo menos, era assim, eu não lia tanto, depois comecei a ter aula de Literatura e comecei a ler mais, me interessar mais pelo romance."B.M.

“Eu acho que, se tirasse as aulas de Literatura, ia fazer falta, como que a gente ia descobrir o livro, a vida do autor e obras, como?” L.J.

“Os professores passam sempre livros e eu acostumei a ler." G.R.

Assim, a escola pode ter sucesso nessa tarefa, mas o contrário também pode ocorrer, fazendo com que o aluno se distancie para sempre da leitura. Já é possível perceber uma preocupação maior com a questão da formação de leitores, entretanto, muitos ainda se sentem presos à estrutura curricular e acabam limitando o ensino a períodos literários e biografia de autores.

“Tudo que é literatura termina com ismo, surrealismo, expressionismo...” R. H. “Só ensina vanguarda.” R.M. 
“A professora comenta os personagens, enredo, escola literária...” M.H.

“Ela (professora) foca mais na vida do autor e acho que a gente devia ler mais os livros, não a vida do autor.” J.G.

A realidade das escolas pesquisadas não trouxe resultados animadores. Parece que, mesmo com o passar dos anos, com os diversos debates e avanços na educação, não se pode dizer que houve uma mudança significativa no ensino da Literatura. Ao contrário, percebemos que os problemas existentes quando éramos alunas da Educação Básica, passados tantos anos, ainda se repetem, como o desinteresse pela leitura e a preocupação da escola em centrar o ensino da Literatura no estudo dos clássicos.

Cada vez torna-se mais difícil trazer os jovens alunos para o mundo dos livros. Zanchetta (2004:92) afirma que a "concorrência do livro com outros meios de comunicação” é uma das principais dificuldades para o início do jovem na leitura. ( "Não gosto, prefiro outras coisas, ficar no msn.” J.D.) A tecnologia adentra a vida de todas as pessoas: internet, televisão, vídeo-game, entre outros meios, desviam a atenção do jovem. Tudo se transforma muito rápido, e as pessoas também devem ser rápidas para acompanhar essas mudanças.

A rapidez da modernidade não combina com o tempo que se leva para ler um livro. O ato de leitura exige paciência, calma, concentração e, principalmente, silêncio. ("Na televisão, você recebe várias notícias, você senta e recebe. Já pra você ler, você tem um esforço maior, você tem que pensar, que raciocinar.” J.F.) Ler, muitas vezes, é um ato solitário e de profunda reflexão. Com toda a velocidade da modernidade, fica muito difícil fazer com que os alunos "parem” para ler. A essa dificuldade de concentração, soma-se o ensino precário da literatura nas escolas. Para Lajolo (1999), na maioria das vezes, os alunos não gostam de ler porque seus professores também não são leitores, não gostam de ler.

Geralmente as obras que os professores leram na vida são as que indicarão aos seus alunos. É imprescindível, portanto, que o professor que se preocupa em formar leitores, em fazer com que seus alunos se “apaixonem” pela leitura, também seja um leitor e, de preferência, “apaixonado”. Dessa forma, ele consegue despertar o gosto de seus alunos. Nas falas de alguns entrevistados, foi possível conhecer histórias de professores apaixonados: 
“Ela era bem empolgada (a professora substituta de Literatura), explicava de maneira mais fácil. Ela não era aquela professora que seguia à risca igual é a nossa de agora, que é tudo certinha. A substituta não ficava presa no livro.” C.P.S.

"Ela fala, brinca, vira um guarda de trânsito, fica com as mãos pra lá e pra cá (imitando a professora), interage com os alunos, todos os professores deviam ser assim. O professor devia subir em cima da cadeira e chamar a atenção.”M.E.R.

“Ela interpreta os poemas, é muito legal!” G.S.

Nessas transcrições, não é possível explicitar o carinho dos alunos ao falar dos professores. Exemplos como os dessas professoras mostram que talvez não sejam necessárias grandes receitas e metodologias de ensino para atrair os alunos. Ao que parece, os estudantes desejam dialogar com alguém que acredite em seu trabalho, "subir em cima da cadeira e chamar a atenção" poderia ser interpretado como o desejo de ter aulas mais dinâmicas. Assim como nesse relato de um aluno sobre um ex-professor de História que o marcou:

“Minha escola não indicava livros, só o professor de História que começou a indicar livros, ele fez uma revolução na escola, todo mundo passou a ler. Ele, antes da aula, no corredor, ele já conversava com os alunos, ele se caracterizava, tinha dia que ele vinha de africano, de índio, então ele se tornava interessante e ele se enturmava muito bem com os jovens e começava a conversar do livro antes e as pessoas iam procurar o livro e começavam a ler, não era obrigado, e vários colegas meus começaram a ler.” J. F.

Esse comentário nos faz refletir sobre a tarefa de formar um leitor, que deve ser um trabalho em comum, não uma responsabilidade centralizada somente no professor de Literatura. Deve ser um esforço de todos os professores, escola e família. Entretanto, o que ocorre, muitas vezes, é um "pacto de mentira" feito entre aluno e professor. Ou seja, os alunos fingem que leem e entendem os textos, e os professores fingem que acreditam. “Daí, talvez, a diferença entre 'ledores', formados pela escola, e 'leitores', tão necessários à sociedade brasileira” (Silva, 1998:11). Mas seria injusto apenas “culpar” os professores por não gostarem de ler. É preciso considerar que, na maioria das vezes, isso é decorrente da trajetória de vida desse profissional, pelo pouco tempo da que dispõe ou até mesmo pelos baixos salários, o que pode dificultar a aquisição de livros, entre outros fatores. 
Para os professores não-leitores, o livro didático (LD) acaba sendo o recurso principal. Ao abordar essa questão, Lajolo (1999) afirma que, na verdade, o LD mais afasta do que atrai os alunos para a leitura. E, tradicionalmente, traz somente fragmentos de textos, e suas atividades vêm prontas para o professor, com respostas “fechadas”, não dando abertura para discussões e tirando do ombro dos professores a responsabilidade de preparar suas aulas, contribuindo para o desinteresse dos alunos e, consequentemente, dos professores em ministrar o conteúdo. Isso sem mencionar as condições de trabalho, salários baixos, disponibilidade de livros para os alunos, entre vários outros.

Ao ouvir as falas dos alunos, acreditamos ainda mais nessa questão do LD. Realmente, se mal abordado, ele pode ser um instrumento que, ao invés de atrair, retrai os alunos em relação à leitura. A maior parte deles reclamou do livro, alegando ser algo cansativo e que faz com que o professor fique preso a ele, não buscando atividades diferenciadas com a turma:

“O professor só fica lendo o livro, falando, falando...” M.H.

“Tudo o que a gente vai fazer é com o LD.” B.G.

Percebi que os alunos sentem necessidade de aulas diferentes, de sair da rotina da sala e do LD:

“Uma aula mais variada, sair, visitar outros lugares.” F.G.

“Debates.” B.G.

"Sair mais da sala, a gente só fica na sala. Na Literatura a gente não sai da sala, as outras sai.” E.L.

"Um passeio no campo, cada um levando um livro, e sentar e ler e discutir." J.F.

Alguns exemplos interessantes também foram apontados:

“Ela (ex-professora) saía do livro, era diversidade, de tudo um pouco, trazia textos diferentes, não só do LD, trazia obras de fora pra gente estudar.” B.G.

"Teve uma vez que ela deu uma peça de teatro pra gente fazer sobre uma obra, 'A Barca do Inferno'. Nós lemos pra fazer e ela discutiu com a gente, muito legal!” F.G.

Esses elogios contrariam certas opiniões que afirmam que os jovens não têm maturidade para avaliar um professor e que eles só sabem "falar mal” dos mesmos. 
Acreditamos que isso possa ocorrer de verdade, mas também acreditamos que os alunos sabem prestigiar e guardar na memória exemplos de bons professores. Para a maioria dos alunos, "ler” é adquirir conhecimentos, aumentar o vocabulário, viajar. Ler, para Jolibert (1994), é atribuir sentidos ao que se lê, a partir de uma expectativa, uma necessidade que a leitura supre. Já Silva (1998) ressalta que, se a leitura feita pelo aluno não tiver relação com seu contexto de vida, e se o contexto do texto lido não proporcionar uma compreensão maior da realidade do leitor, o texto perde seu sentido e não desperta o interesse para essa atividade. É “na leitura e na escritura do texto que encontramos o senso de nós mesmos e da comunidade a que pertencemos” (Cosson, 2006:17). A leitura descontextualizada, que não leva em conta a realidade dos alunos, é muito comumente feita na escola, por isso, não se vê prazer e os educandos só leem objetivando uma nota e aprovação na disciplina.

As leituras exigidas pela escola continuam sendo as mesmas de tempos atrás, como Dom Casmurro, Memórias Póstumas de Brás Cubas, Memórias de um Sargento de Milícias, Macunaíma, entre outros clássicos. Os professores alegam a importância dessas obras devido à sua grande cobrança nos vestibulares. Após essas leituras, os professores aplicam atividades interpretativas e provas.

“Os alunos não estão mais lendo por vontade, estão lendo pra ter nota no final do bimestre, deveria mudar isso, o Brasil inteiro tá assim. Deveriam ler para aprender, não para nota.” M.E.R.

“Memórias Póstumas de Brás Cubas. Só li porque tinha prova pra fazer.”J.G.

“Acho que não deveria ser aplicada prova de um livro, e sim debater, falar sobre ele." J.K.

“Não gostei, achei um livro (Memórias Póstumas de Brás Cubas) muito complicado pra se ler.” M.L

Paulo Freire (1981) afirma que a leitura não é somente a decodificação de palavras, vai muito além disso. Lemos algo quando vemos sentido em alguma coisa. A leitura não se limita somente a textos escritos, pode-se fazer leituras de situações, objetos, imagens, ou seja, uma leitura do mundo. Quando algo nos desperta alguma reação, é porque fizemos uma leitura, e não somente enxergamos ou decodificamos o texto. Quando percebemos algum sentido no texto lido, é devido à relação feita com alguma experiência de nossa vida; nesse momento, é possível afirmar que foi feita uma 
leitura. Se não houver compreensão, não há leitura. "Ler é, antes de tudo, compreender” (Silva, 1992:67).

Muitos alunos reclamaram da dificuldade de compreender algumas obras solicitadas, pois, de acordo com eles, a linguagem é difícil e muito diferente da linguagem atual. Dessa forma, não ocorre uma leitura profunda, limitando-se a leitura somente ao esforço da decodificação das palavras. Contudo, concordamos e sabemos da grande importância de levar os clássicos para a sala de aula. Mas acreditamos que a abordagem deveria ser diferente. Obrigar os alunos a ler com o objetivo de aplicar avaliações posteriores não é a melhor alternativa. É importante fazer um esforço para relacionar essas obras com algum aspecto da realidade dos alunos. Mas, nas práticas escolares, raramente se leva em consideração a realidade, enfiando "goela abaixo" livros que não trazem significado nenhum para a vida dos educandos, textos que, para eles, dentro de suas realidades, não dizem nada. O melhor livro para o aluno ler é aquele que faz algum sentido em sua vida, não histórias e mundos distantes do mundo vivido por ele. Por isso é tão importante o professor tentar fazer essa aproximação entre os contextos para que as leituras pedidas sejam interessantes e façam "ponte” com as vidas dos alunos, propiciando prazer, para que, assim, o gosto pela leitura desperte.

“O chato é que os professores mandam a gente ler, tipo, esses autores, daí nas aulas, afasta a vontade de ler, porque esses clássicos são chatos realmente, e eles não incentivam a ler livros prazerosos, que a gente gosta mesmo. Eles manda aqueles autores que fala muito difícil, a gente não entende e com isso fica uma leitura muito chata, cansativa e desgastante.” M.E.R.

O depoimento do aluno dá pistas sobre a recusa ao texto clássico. Ele não se mostra resistente à leitura, apenas não dialoga com a obra proposta e, por isso, ela se torna difícil. Alguns professores entendem a importância de relacionar as obras estudadas com algum aspecto da realidade de seus alunos e buscam fazer esse esforço, como verificado na fala de alguns entrevistados:

“Eu gosto dela porque no pouco que ela vai falar, por exemplo, do Barroco, ela tenta entrar em alguma coisa que a gente vê no nosso dia-a- dia pra gente associar, ela faz isso.” J.H.

"Gosto dessas histórias que entra um pouco no que a gente vive, que seja meio real e, ao mesmo tempo, que você possa viajar."A.C. 
É imprescindível o contato dos alunos com essas obras. Mas, assim como o ato de ler exige esforço e trabalho, a formação de um leitor também exige o mesmo esforço e trabalho do professor. Alunos que não costumam ler e são obrigados a ler obras que, para eles, são complexas devido à linguagem e época diferente da deles, quando se deparam com obras assim, acabam se “assustando” e criando uma aversão à leitura. Uma boa alternativa para atraí-los para a leitura de Dom Casmurro é partir da leitura do livro O Bom ladrão, de Fernando Sabino, obra esta que já foi exigida para uma prova por uma dessas escolas, e os alunos foram obrigados a ler - no entanto, essa leitura agradou a todos. Esse livro é uma revisitação dos personagens Bentinho e Capitu. Nele há uma relação de intertextualidade com a obra de Machado de Assis, além de relacionar outras obras importantes, como O Primo Basílio, de Eça de Queiroz, e a Causa Secreta, conto machadiano. Essa leitura, se bem mediada pelo professor, pode despertar a curiosidade de ler os clássicos abordados nessa história. Essa discussão também se verifica nos Parâmetros Curriculares Nacionais do Ensino Médio:

\begin{abstract}
O aluno vive num mundo de fatos regidos pelas leis naturais e está imerso num universo de relações sociais. Está exposto a informações cada vez mais acessíveis e rodeado por bens cada vez mais diversificados, produzidos com materiais sempre novos. Está exposto também a vários tipos de comunicação pessoal e de massa. O cotidiano e as relações estabelecidas com o ambiente físico e social devem permitir dar significado a qualquer conteúdo curricular, fazendo a ponte entre o que se aprende na escola e que se faz, vive e observa no dia-a-dia (2002, p. 94).
\end{abstract}

Dizer que os alunos não gostam de ler é muito cômodo. Por que não partir da realidade do aluno, do que eles já têm, ou seja, partir das leituras que os alunos já fazem para inserir, aos poucos, leituras mais complexas? Dessa forma, os alunos vão se “rendendo” e, quando se derem conta, já terão se tornado leitores assíduos. Para que isso ocorra, os professores deveriam valorizar as leituras de seus alunos, ao invés de rotulá-las como ruins.

\title{
SURPRESAS QUE CONFRONTAM O SENSO COMUM
}

O que chamou muito a atenção durante o levantamento do corpus de trabalho foi descobrir que os alunos leem, sim, ao contrário do que se costuma afirmar. Mas, contrariando os professores, não leem o que é exigido pela escola. Os jovens não têm como leituras preferidas as obras canônicas e clássicas, como a escola gostaria que fosse. Mas “devoram” livros de auto-ajuda e best-sellers que são tão marginalizados 
pelos professores. Livros como Crepúsculo, Lua Nova, O Código da Vinci, Harry Potter, Anjos e Demônios, e vários classificados como de auto-ajuda (Vendedor de Sonhos, O Código da inteligência, A arte da felicidade, Nunca desista de seus sonhos), além de outros títulos citados, estão entre os preferidos deles.

“Ou então, sei lá, (os professores) começar a se interessar pelos autores atuais, não ficar só no passado, só porque eles fizeram história no passado, então acho que tem muitos de agora que merecem também ser...acho que também devia valorizar autores internacionais.” S.P.

E alguns contaram empolgadamente porque gostam de ler esses livros:

“Tem suspense, detalhes.” (todos)

“Você lendo o livro, você dá risada sozinho.” M.P.

"Você quer saber o que vai acontecer em cada capítulo e não consegue parar." J.F.

“Eu lembro que cheguei a ler num dia 150 páginas do livro.” M.P.

“Li praticamente o livro inteiro num só dia.” S.G.

Não devemos ignorar que essas manifestações demonstram quanto esses alunos podem se tornar leitores literários, “estão no caminho”, viajam na leitura, esquecem do tempo, se sentem presos e dentro da história. Demonstram que têm a percepção de elementos da narrativa, como o clímax, a descrição, o desfecho etc.

Os alunos que declararam que não gostam de ler também leem essas obras marginalizadas pela escola, o que nos faz indagar: será que devemos continuar desprezando essas leituras?

Ficamos curiosas em saber como surgiu a vontade nesses alunos de lerem essas obras. Foram unânimes em dizer que foi através de amigos que leram e emprestaram, e costumam trocar os livros entre si. Um fala para o outro e a leitura vai se disseminando. Acredito também que os jovens se interessam mais por esses livros porque todos os colegas estão lendo, e é uma forma de se sentir incluído no grupo. Isso ilustra muito bem a função social que o livro também tem.

Não se deve atribuir toda a responsabilidade de formar leitores somente ao professor. Para isso, de acordo com as idéias de Silva (1986), deveria haver um esforço conjunto da família e da comunidade escolar. Em casa, os pais deveriam servir de exemplo para seus filhos, lendo e incentivando-os a ler. Na escola, o aluno também 
deveria ser incentivado. A biblioteca teria de contar com um amplo acervo e uma bibliotecária que estimulasse os alunos a ler. O currículo da escola também deveria “abrir espaço” para as atividades dedicadas à leitura e à formação de leitores, e os professores não deveriam utilizar o livro somente como uma ferramenta metodológica, mas sim, como um instrumento de transformação social. Esse contexto seria o mais propício para formação de um leitor.

Nas escolas pesquisadas, verificamos o amplo acervo das bibliotecas. Contam com um ambiente propício para a leitura e uma grande variedade de obras. Entretanto, a realização de atividades na biblioteca, na maioria das vezes, só ocorre durante o Ensino Fundamental, perdendo-se esse hábito ao alcançar o Ensino Médio. Assim, os alunos perdem o costume de frequentá-la. Eles só se dirigem até lá para pegar algum livro que o professor manda, ou esse lugar acaba se tornando, às vezes, “quebra-galho”, deixando-se de aproveitar esse espaço para o incentivo da leitura.

“Ia na Biblioteca mais no Ensino Fundamental.” A.F.

“É mesmo, quando era pequenininha, adorava ir na Biblioteca da escola, pegava livrinhos e ficava lendo.” F.P

“O último que eu li é 'O beijo no asfalto’. Foi quando o colégio tava em obras, daí a gente foi ter aula na biblioteca, porque não tinha sala, aí eu vi esse livro e peguei. J.P

“O que eu tô lendo agora é o 'Pensamento vivo de Karl Marx'. Tô lendo por conta própria, eu que achei na biblioteca na escola.” A.F.

Outro ponto muito importante das entrevistas foi a discussão sobre como seria uma aula interessante de Literatura:

“Gostava da aula dela porque ela interagia com a gente, todo mundo gostava da aula dela, participava, respondia.” J.H.

“Não era aquela aula cansativa.” M.P.

“A professora tem que ser mais interativa, trazer mais coisas para o aluno participar, diferente, não aquela rotina, não só ler, ler, ler, fica muito maçante.” M.E.H.

Os alunos sentem necessidade da interação em sala de aula. Muitos reclamaram de que o conteúdo não é debatido, professores até demonstram irritação quando os alunos participam: 
“A professora não gostava que eu me intrometia na aula dela, então acho que fui com nota baixa em Literatura por causa disso.” J.F.

Eles também percebem e são contaminados pelo ânimo do professor em sala de aula:

"O professor que chega na aula, já chega com cara de morto, como quer que o aluno aprenda, interaja com a aula? O aluno, ele também, se já tá um pouco pra baixo, ele vai ficar mais pra baixo ainda. Acho que o professor tinha que ter a noção, a sabedoria e dizer: "não, vou chegar alegre e descontraído, vou interagir a aula, hoje vai ser uma aula diferente, vamos pra fora, passear...” M.E.H.

A observação desse aluno mostra como é importante que o professor seja capaz de entrar na sala de aula e deixar seus problemas particulares "pra fora”, o que não é tarefa fácil. O professor, cada vez mais, acumula funções, e a mais nova delas é ser “ator”. Por essas e outras, essa profissão merece uma valoração maior do que a que é dada atualmente. Quando ocorrer a valorização do professor e uma revolução no ensino da leitura, ocorrerá a tão sonhada revolução na educação brasileira. Essa importância se dá porque, através da leitura, é possível compreender o mundo em que vivemos com um olhar crítico e, assim, transformá-lo. Quanto mais as pessoas cultivarem o hábito da leitura, mais difícil será ludibriá-las e, assim, os políticos corruptos terão mais dificuldades em ser eleitos. Essa preocupação está presente no PPP do Ensino Médio da Escola Menodora. O PPP dessa escola tem como um dos objetivos específicos "o aprimoramento do educando como pessoa humana, incluindo a formação ética e o desenvolvimento da autonomia intelectual e do pensamento crítico” (PPP -Menodora Fialho de Figueiredo, 2008, p.29). Não foi possível o acesso ao PPP da outra escola pesquisada.

A leitura propicia conscientização e libertação, é uma forma de "sair da rotina robotizante, da pressão conformista que a sociedade de consumo tenta nos impor a todo momento” (Silva, 1986, p. 48). Não existem técnicas, receitas prontas para despertar o gosto pela leitura nos alunos, pois cada realidade é diferente, assim como cada aluno. Se o professor se preocupar em conhecer a origem e realidade dos estudantes e partir daquilo que eles têm, ou seja, usar as experiências que seus alunos trazem consigo como ponto de partida para suas atividades com a leitura, já terá grandes chances de conquistá-los. Assim, o professor pode inserir, aos poucos, leituras de livros que 
apresentem outra possibilidade de vida, outra realidade. Dessa forma, o livro, além de proporcionar uma experiência de prazer, também será um instrumento de transformação da realidade e de elevação cultural desses alunos. Portanto, a escola é que deve se adequar à vida do aluno, e não exigir o contrário.

Através da leitura, temos contato com outros mundos, com outras formas de vida, e passamos a imaginar como seria a vida de outra forma, o que nos dá vontade de mudar, de transformar nossas vidas e a sociedade em que vivemos. A leitura permite a ampliação de nossos horizontes e visões de mundo. Conhecendo outras realidades, nos tornamos mais tolerantes com o próximo.

De acordo com Graça Paulino e Rildo Cosson, as aulas de Literatura:

\begin{abstract}
Devem ter como horizonte a formação de um sujeito da linguagem, de um produtor de textos, de um leitor que tenha a competência de interagir com a literatura em várias frentes, selecionando livros, identificando diferentes suportes com seus intertextos e articulando contextos de acordo com seus interesses pessoais e da sua comunidade. Acima de tudo, deve ter como objetivo último a interação verbal intensa e o (re)conhecimento do outro e do mundo que são proporcionados pela experiência da literatura (2009, p. 76).
\end{abstract}

Muitas vezes, uma boa aula de Literatura é pensada somente como a simples leitura de textos literários. Mas, além dessas leituras, é preciso um aprofundamento maior, é necessária a promoção do letramento literário nas escolas. A partir da Literatura, pode-se viver outras experiências, outras vidas, sem deixar de ser quem somos. Ela proporciona uma compreensão melhor do mundo e nos humaniza. A disciplina de Literatura, atualmente, não é tratada com grande valor pelos currículos escolares, que reservam para ela pouquíssimas aulas durante a semana, como verificado no PPP de uma das escolas pesquisadas. Para os alunos, a sua importância está atrelada aos vestibulares. Portanto, deve-se reconhecer a função social da Literatura. Precisamos mudar o olhar e o tratamento da escola para com ela, para que possamos ouvir, cada vez mais, falas como essas:

"Pra mim, quanto mais leio mais eu tô na história, então esse mundo daqui eu deixo completamente e entro completamente no mundo dentro da história, então pra mim é um refúgio." J.P.

“Ler pra mim é uma paixão (...).” M.E.H

“Adoro, tá no meu sangue. Começou com um livro simples, por acaso, sem obrigação, aí comecei a gostar da leitura, e entrei na leitura e não saí mais.” J.F 
Esses depoimentos apontam que o esforço de formar um leitor, seja da comunidade escolar ou da família, é de grande valia. Quando se consegue conquistar jovens para o mundo dos livros, não se está contribuindo somente para a ampliação de seu vocabulário ou para melhorar sua escrita, mas também para o conhecimento de novas possibilidades de vida, para o exercício da alteridade e para a formação de cidadãos críticos e em busca de mudanças.

\section{CONCLUSÃO: INÍCIO DE UMA LONGA CAMINHADA}

A pesquisa objetivava verificar se as leituras realizadas são indicadas pela escola ou outros meios, perceber se os alunos estão lendo por prazer ou devido a alguma obrigação (tarefa escolar, vestibular etc), observar se os alunos estão deixando a escola como leitores ou não-leitores e identificar a opinião deles em relação às aulas de Literatura. Ao final do levantamento das entrevistas, ficou mais nítida a realidade dessas escolas pesquisadas.

De maneira geral, percebemos que os alunos leem, sim, mas não leituras que a escola cobra. As exigidas pela escola são lidas para obter uma nota e porque algumas são exigidas no vestibular. Em relação à formação de leitores literários, acreditamos que esses alunos ainda não estão formados, mas têm grandes chances de se formar, pois estão no caminho da leitura. Muitos buscam leituras por conta própria, poucos são incentivados pela família e há troca de livros com amigos. A escola também utiliza o "sistema da troca": o aluno lê e o professor dá nota. Felizmente, nesse "sistema de trocas”, existem algumas obras que chamam a atenção dos alunos, como O Bom Ladrão (Sabino, 1992), que foi exigida para uma prova, mas todos os alunos adoraram. Enfim, este artigo pretendeu discutir a leitura do ponto de vista dos alunos. É importante destacar que é necessário, antes de generalizar, de repetir discursos como “os alunos não gostam de ler”, fazer um estudo de cada realidade para, a partir disso, pensar formas de trabalhar e incentivar a leitura.

Não se pode negar que ainda existem muitos problemas na educação e, especificamente, no ensino da leitura. Problemas estes que, na sua maioria, são os mesmos de anos atrás, como acomodação de professores, alunos desinteressados/desmotivados, entre vários outros discutidos neste artigo. Essa conclusão já era esperada de se encontrar. Mas, entre tantos relatos, tivemos a felicidade de deparar com histórias e personagens interessantes, como alguns alunos e professores 
que amam ler. Professores que se esforçam para conquistar seus alunos e que, dentro da sala de aula, promovem suas pequenas “revoluções”. Professores que não são vistos, não são reconhecidos e algumas vezes não são valorizados, mas que, mesmo assim, continuam acreditando no que fazem e ainda trazem um brilho nos olhos. Professores que exercem sua profissão com amor e dedicação, mas que estão escondidos e não aparecem nas estatísticas. No entanto, estão registrados em um lugar de maior importância: na lembrança de seus alunos, onde deixam marcas e agradecimentos para uma vida inteira. Quando decidimos pesquisar sobre a formação de leitores, o fizemos com receio de que esse assunto já estivesse saturado de discussões, e de que nos tornássemos repetitivas, mas, chegando ao fim deste artigo, percebemos que nos enganamos, e que ainda se tem muito para pesquisar e relatos inovadores para conhecer, o que ainda nos faz acreditar na Educação.

\section{REFERÊNCIAS}

Azevedo, R. (2004). Formação de leitores e razões para a Literatura. In: R. J. de Souza. Caminhos para a formação do leitor 38-47. São Paulo, SP: DCL.

Brasil, SEB. (2002). Parâmetros Curriculares Nacionais do Ensino Médio (PCNEM). Brasília, DF.: MEC/SEB.

Cosson, R. (2006). Letramento literário: teoria e prática. São Paulo: Contexto.

Fernandes, M. D. E. \& Freitas, D. N. T. de. (2009). Percursos e Desafios da Municipalização do Ensino Fundamental em Dourados, MS.

(colhido em 10/07/2009).

. http://www.revistas.ufg.br/index.php/interacao/article/viewFile/1331/1367

Freire, P. (1981). A Importância do Ato de Ler: em três artigos que se completam. 22 ed. São Paulo, SP: Cortez.

INSTITUTO PRÓ-LIVRO $\overline{10 / 07 / 2009) .}$

Jolibert, J. (1994) Formando crianças leitoras (trad. Magne, B. C.). Porto Alegre: Artes Médicas.

Lajolo, M. (1999). Do mundo da Leitura para a Leitura do Mundo. 5 ed. São Paulo: Ática. 
Paulino, G. \& Cosson, R. (2009). Letramento literário - para viver a literatura dentro e fora da escola. In. R. Zilberman \& T. M. K. Rösing (orgs.) Escola e leitura: velha crise, novas alternativas p. 61-79. São Paulo, SP: Global. (Coleção Leitura e Formação).

PROJETO POLÍTICO PEDAGÓGICO (PPP - Escola Estadual Menodora Fialho De Figueiredo), 2007.

Sabino, F. (1992). O Bom Ladrão. São Paulo: Ática.

Silva, E. T. da. (1998). Elementos de pedagogia da leitura. 3 ed. São Paulo: Martins Fontes. - (Texto e Linguagem).

. (1992). O Ato de Ler: fundamentos psicológicos para uma nova pedagogia da leitura. 6 ed. São Paulo: Cortez. (1986). Leitura e Realidade Brasileira. 3 ed. Porto Alegre: Mercado Aberto.

Soares, M. (1999). Letramento: um tema em três gêneros. 2. ed. Belo Horizonte:

Autêntica.

WORLD REPORT REPORTS WORLDWIDE 10/07/2009).

http://www.universia.com.br/materia/materia.jsp?id=16012 (colhido em

Zanchetta, J. (2004). Leitura de narrativas juvenis na escola. In: R. J. de Souza. Caminhos para a formação do leitor 92-109. São Paulo, SP: DCL.

Zilberman, R. (org.) (1984). Leitura em crise na escola - as alternativas do professor. Porto Alegre: Mercado Aberto.

\section{AS AUTORAS}

Mayara Regina Pereira Dau é Mestranda em Letras pela Universidade Federal da Grande Dourados (UFGD) e graduada em Letras com habilitação em Língua Portuguesa e Literatura pela mesma instituição no ano de 2009. Seus interesses de pesquisa incluem a resistência de jovens leitores à leitura canônica.

E-mail: mayarabrt@hotmail.com

Alexandra Santos Pinheiro é doutora pela Universidade Estadual de Campinas e professora adjunta da Universidade Federal da Grande Dourados, onde leciona na gradução e no mestrado. Pesquisa na área da história da leitura e do letramento literário. E-mail: alexpin24@yahoo.com.br 